\title{
Incremental Increases in Glucocorticoid Doses May Reduce the Risk of Osmotic Demyelination Syndrome in a Patient with Hyponatremia due to Central Adrenal Insufficiency
}

\author{
Katsunobu Yoshioka ${ }^{1}$, Mieko Minami ${ }^{1}$, Shunsuke Fujimoto ${ }^{2}$, Seiko Yamaguchi ${ }^{2}$, \\ ${\text { Kenji } \text { Adachi }^{2} \text { and Keiko Yamagami }}^{3}$
}

\begin{abstract}
A 50-year-old man was admitted to our hospital because of general malaise. Laboratory tests revealed severe hyponatremia $(104 \mathrm{mEq} / \mathrm{L})$, which was attributed to central adrenal insufficiency. To treat presumed central diabetes insipidus (CDI), we administered a small dose of hydrocortisone and gradually increased it to maintenance doses to prevent osmotic demyelination syndrome (ODS). Serum sodium levels did not increase more than $10 \mathrm{mEq} / \mathrm{L} /$ day and ODS did not occur. Thereafter, the patient was proven to have CDI. Incremental increases in glucocorticoid dose may reduce the risk of ODS for patients with hyponatremia due to central adrenal insufficiency, especially that complicated by CDI.
\end{abstract}

Key words: glucocorticoid replacement, hyponatremia, central adrenal insufficiency, osmotic demyelination syndrome

(Intern Med 51: 1069-1072, 2012)

(DOI: 10.2169/internalmedicine.51.6507)

\section{Introduction}

Osmotic demyelination syndrome (ODS) is a neurologic condition that occurs after the rapid correction of serum sodium in patients with hyponatremia (1). Once ODS develops, it cannot be specifically treated and the neurological prognosis is dismal. Therefore, it is very important to prevent the development of ODS. It is well recognized that the risk of ODS is greater in patients with malnutrition, alcoholism, and extreme hyponatremia (2). Replacement of glucocorticoids (GC) in patients with central adrenal insufficiency may be another risk factor (3). However, GC replacement is required to treat hyponatremia due to GC deficiency. Although Lasheen et al. advocated use of the lowest possible dose of GC in such situations along with the close monitoring of serum sodium levels (3), a specific treatment plan was not provided. As such, there have been no guidelines for GC replacement in patients with hyponatremia due to GC deficiency.
We report a patient with severe hyponatremia due to GC deficiency who was successfully treated without development of ODS. GC replacement was achieved with small incremental increases in dose. We compare reports of patients who developed ODS during GC replacement with our case, and the rationale for using our method is discussed.

\section{Case Report}

A 50-year-old man was admitted to our hospital because of severe general malaise and mild impairment of consciousness. He had been treated with olmesartan, allopurinol, and fenofibrate for treatment of hypertension, hyperuricemia, and hyperlipidemia, respectively. Seven days before admission to our department, the patient developed a severe headache and was admitted to another department of our hospital. Magnetic resonance imaging revealed a cystic lesion in the sella turcica compatible with Rathke's cleft cyst. His serum sodium level was $129 \mathrm{mEq} / \mathrm{L}$. On the following day, the patient's headache subsided and he was discharged. Four

${ }^{1}$ Department of Internal Medicine, Osaka City Sumiyoshi Hospital, Japan, ${ }^{2}$ Department of Gastroenterology, Osaka City Sumiyoshi Hospital, Japan and ${ }^{3}$ Department of Internal Medicine, Osaka City General Hospital, Japan

Received for publication September 5, 2011; Accepted for publication January 23, 2012

Correspondence to Dr. Katsunobu Yoshioka, kmyoshi@rr.iij4u.or.jp 


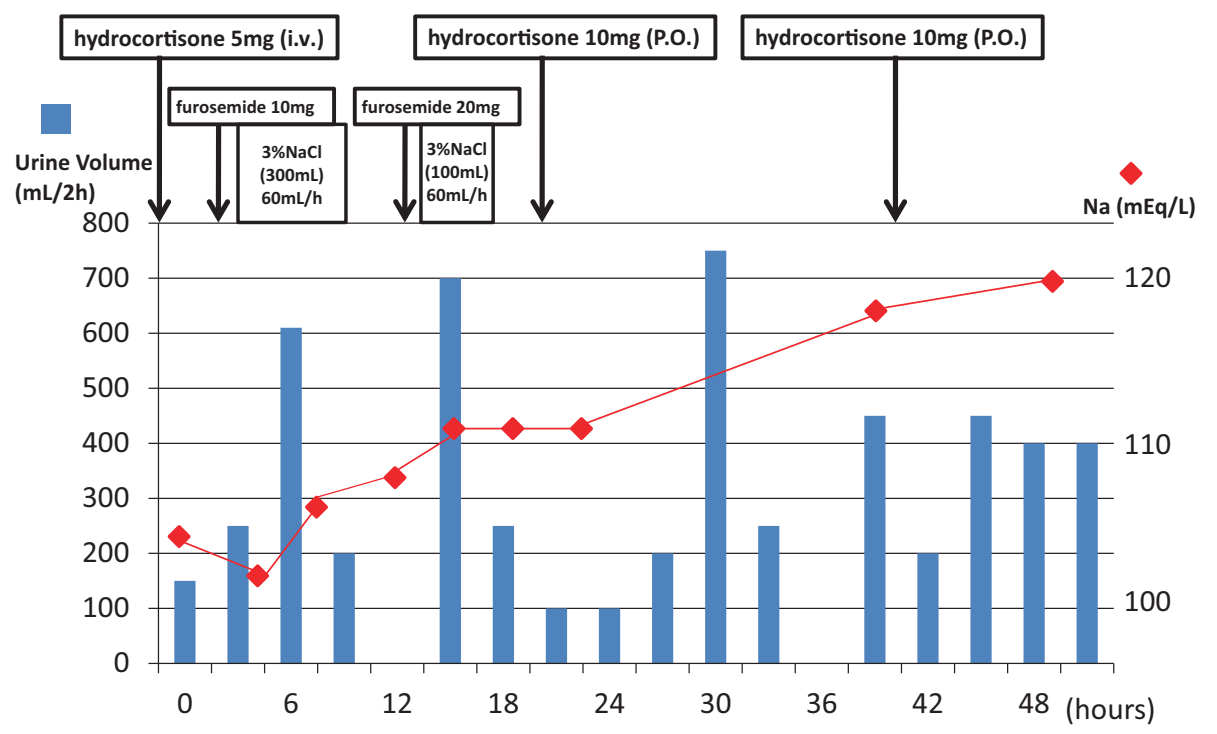

Figure 1. Clinical course showing first 48 -hour serum sodium and urine volumes.

days before admission, he was referred to our department and admission was scheduled for further evaluation and treatment. However, over the next 3 days he experienced progressive general malaise and visited our department. Laboratory tests revealed severe hyponatremia $(104 \mathrm{mEq} / \mathrm{L})$ and the patient was admitted. On admission, although he was drowsy and inactive, he could give relevant answers to questions. His blood pressure was $110 / 70 \mathrm{mmHg}$ and pulse rate was 80 beats per minute. He was $160 \mathrm{~cm}$ in height and weighted $56 \mathrm{~kg}$. Physical examinations were unremarkable. Laboratory data was as follows: plasma glucose: $94 \mathrm{mg} / \mathrm{dL}$, creatinine: $0.67 \mathrm{mg} / \mathrm{dL}$, blood urea nitrogen: $4.3 \mathrm{mg} / \mathrm{dL}$, uric acid: $2.8 \mathrm{mg} / \mathrm{dL}$, sodium: $104 \mathrm{mEq} / \mathrm{L}$, potassium: $4.2 \mathrm{mEq} /$ $\mathrm{L}$, chloride $72 \mathrm{mEq} / \mathrm{L}$, serum osmolality: $211 \mathrm{mOsm} / \mathrm{kg} /$ $\mathrm{H}_{2} \mathrm{O}$, urinary osmolality: $381 \mathrm{mOsm} / \mathrm{kg} / \mathrm{H}_{2} \mathrm{O}$, urinary sodium: $72 \mathrm{mEq} / \mathrm{L}$, and urinary potassium: $34 \mathrm{mEq} / \mathrm{L}$. Endocrinologic data revealed a mild decrease in thyroidstimulating hormone (TSH) level $(0.071 \mu \mathrm{IU} / \mathrm{mL})$ and free T4 level was at the lower limit of normal $(0.9 \mathrm{ng} / \mathrm{dL})$. We concluded that the cause of hyponatremia was central adrenal insufficiency based on the existence of a Rathke's cleft cyst and laboratory findings. Therefore, after completing the corticotrophin-releasing hormone $(\mathrm{CRH})$ test, we began to correct hyponatremia.

Although we recognized that GC replacement is required to correct hyponatremia, we initially administered a low dose of hydrocortisone $(5 \mathrm{mg})$ intravenously to prevent the onset of ODS. Concomitant use of $3 \%$ saline was avoided. However, 3 hours later, urine volume did not increase, and serum sodium level dropped to a nadir of $102 \mathrm{mEq} / \mathrm{L}$. Therefore, sodium correction was performed with $3 \%$ saline together with furosemide, and serum sodium level increased to $106 \mathrm{mEq} / \mathrm{L}$ and $108 \mathrm{mEq} / \mathrm{L}, 8$ and 12 hours after starting therapy, respectively (Fig. 1). Three percent saline and furosemide were administered intermittently so that serum sodium levels did not increase too rapidly. Eighteen hours after starting therapy, the serum sodium level rose to 111
$\mathrm{mEq} / \mathrm{L}$ and his consciousness level improved. However, blood pressure dropped to $80 / 50 \mathrm{mmHg}$ and we administered $10 \mathrm{mg}$ of hydrocortisone. Following this treatment, the patient's blood pressure rose to $108 / 60 \mathrm{mmHg}$ and serum sodium level increased gradually without using additional $3 \%$ saline. Forty-eight hours after starting therapy, the patient's serum sodium level rose to $120 \mathrm{mEq} / \mathrm{L}$, which represented an increase of $18 \mathrm{mEq} / \mathrm{L}$ in 48 hours.

By this time results of the remaining laboratory examinations at admission were available and showed decreased cortisol and adrenocorticotropic hormone (ACTH) levels (0.8 $\mu \mathrm{g} / \mathrm{mL}$ and $3.6 \mathrm{pg} / \mathrm{mL}$, respectively). Although ACTH response to $\mathrm{CRH}$ was normal, cortisol response to $\mathrm{CRH}$ was low (maximum $4.9 \mu \mathrm{g} / \mathrm{mL}$ ), suggesting that the affected lesion exists above the pituitary level. Serum argininevasopressin (AVP) was detected $(1.63 \mathrm{pg} / \mathrm{mL})$ despite low serum osmolality $\left(211 \mathrm{mOsm} / \mathrm{kg} / \mathrm{H}_{2} \mathrm{O}\right)$.

The dose of hydrocortisone was gradually increased to maintenance doses $(20 \mathrm{mg})$ over 4 days and serum sodium level normalized 7 days after starting therapy (Fig. 2); no neurological deficit developed. However, 10 days after the start of the therapy, the patient developed polyuria of more than 3.0 L/day and his serum sodium level rose to $146 \mathrm{mEq} /$ L. Urinary osmolality decreased to a nadir of $115 \mathrm{mOsm} / \mathrm{kg} /$ $\mathrm{H}_{2} \mathrm{O}$. We diagnosed the patient with central diabetes insipidus (DI) unmasked by GC replacement and he was treated with 1-desamino-8-D-arginine vasopressin (dDAVP). Thereafter, urine volume was reduced and serum sodium levels were stabilized. On day 15 , he was transferred to the neurosurgical unit for operative treatment.

\section{Discussion}

Central adrenal insufficiency is one of the important causes of hyponatremia $(4,5)$. Because cortisol is a physiological tonic inhibitor of AVP secretion (6), hyponatremia in patients with central adrenal insufficiency is mainly 


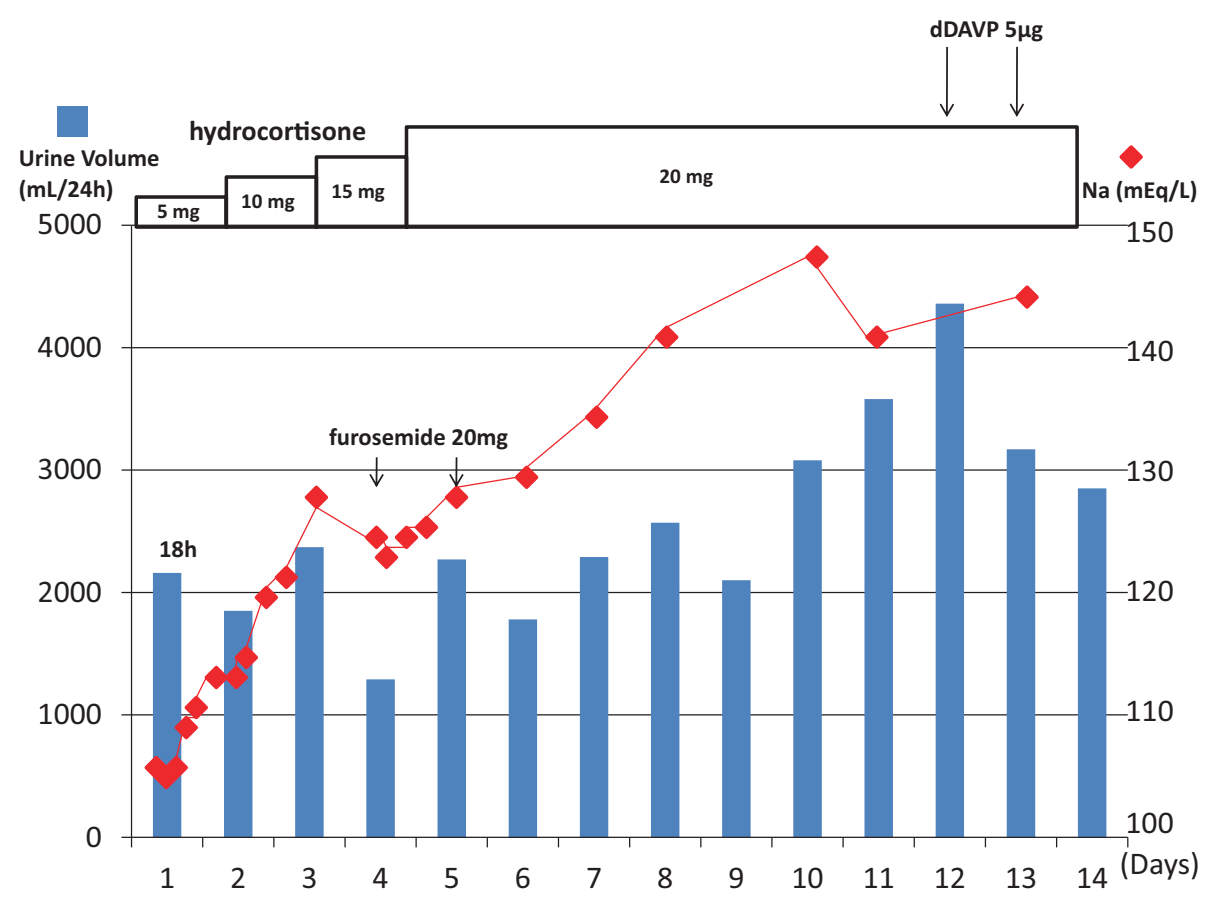

Figure 2. Clinical course showing first 14-day serum sodium and urine volumes. dDAVP: 1desamino-8-D-arginine vasopressin

Table 1. Reported 3 Cases of GC Deficiency-induced Hyponatremia who Developed ODS during the Treatment with GC

\begin{tabular}{|c|c|c|c|c|c|}
\hline case & $\begin{array}{c}\text { First Author } \\
\text { [Ref] }\end{array}$ & $\begin{array}{c}\text { Underlying } \\
\text { disease }\end{array}$ & $\begin{array}{l}\text { Initial serum } \\
\text { sodium level } \\
\quad(\mathrm{mEq} / \mathrm{L})\end{array}$ & Treatment & $\begin{array}{l}\text { Correction of } \\
\text { serum sodium }\end{array}$ \\
\hline 1 & $\begin{array}{l}\text { Shoji M } \\
\text { [12] }\end{array}$ & $\begin{array}{l}\text { Sheehan } \\
\text { syndrome }\end{array}$ & 96 & $\begin{array}{l}\text { Hydrocortisone } 100 \\
\text { mg and } 3 \% \text { saline } \\
\text { within } 48 \text { hours }\end{array}$ & $\begin{array}{c}44 \mathrm{mEq} / 2 \text { days } \\
(96 \rightarrow 142)\end{array}$ \\
\hline 2 & $\begin{array}{l}\text { Lasheen I } \\
\text { [3] }\end{array}$ & $\begin{array}{l}\text { Pituitary } \\
\text { adenoma }\end{array}$ & 105 & $\begin{array}{l}\text { Dexamethasone } \\
4 \mathrm{mg}\end{array}$ & $\begin{array}{c}30 \mathrm{mEq} / 2 \text { days } \\
(105 \rightarrow 135)\end{array}$ \\
\hline 3 & $\begin{array}{c}\text { Lee WC } \\
{[11]}\end{array}$ & Empty Sella & 116 & $\begin{array}{c}\text { Hydrocortisone } 100 \\
\text { mg q8h for } 3 \text { days }\end{array}$ & $\begin{array}{c}21 \mathrm{mEq} / 3 \text { days } \\
(121 \rightarrow 142)\end{array}$ \\
\hline
\end{tabular}

GC, glucocorticoid; ODS, osmotic demyelination syndrome

caused by reduced inhibition of AVP together with excessive water intake. Replacement of GC in patients with hyponatremia due to GC deficiency inhibits the secretion of AVP and may cause rapid free water excretion with excessively rapid normalization of serum sodium. This is one reason that the replacement of GC in patients with GC deficiency is considered a risk factor for developing ODS. The risk is increased in patients with central adrenal insufficiency complicated by central DI. Because the half-life of AVP is short (15-20 minutes), this rapid free water excretion may appear shortly after the replacement of GC. Furthermore, GC replacement can cause free water excretion not mediated by AVPdependent mechanisms, such as changes in systemic and renal hemodynamics (7).

While replacement of GC can be a risk factor for the development of ODS, it has been reported that preexisting central adrenal insufficiency itself may increase the risk of myelin damage (8). Data from an animal model showed that early GC treatment can prevent blood-brain barrier disruption, and as such, GC might be effective in preventing ODS (9). Furthermore, infusion of hypertonic saline was found to be less effective in some patients with hyponatremia due to GC deficiency (5). Taken together, we concluded that GC administration was necessary in the present case. Concomitant use of $3 \%$ saline was avoided because it may cause rapid correction of hyponatremia (10).

In deteminig the initial dose for GC replacement, we searched the literature and found 3 cases in which ODS developed during GC replacement for hyponatremia due to central adrenal insufficiency $(3,11,12)$. The characteristics of these 3 patients are shown in Table 1. Large doses of GC were administered and rapid normalization of serum sodium was achieved.

We believed that a large dose of GC should be avoided in order to prevent the onset of ODS. Furthermore, the patient's GC deficiency was based on Rathke's cleft cyst, 
which is frequently accompanied by central DI (13). Although the current patient did not present with polyuria, polyuria may be absent in patients with central DI when they also experience GC deficiency; this phenomenon is known as "masked DI". Therefore, it is difficult to suspect the coexistence of central DI before starting GC replacement therapy in these patients. In patients with masked DI, we frequently observe rapid free water excretion even after administration of a maintenance dose of GC. With the suspicion of coexistence of central DI in the present case, we initially administrated a small amount of hydrocortisone (5 $\mathrm{mg}$ ) and gradually increased to maintenance doses $(20 \mathrm{mg}$ ) over 4 days in order to prevent ODS. Serum sodium levels were closely monitored and furosemide and $3 \%$ saline were used intermittently. Using this method, the serum sodium levels did not increase more than $10 \mathrm{mEq} / \mathrm{L} /$ day and ODS did not occur.

Ten days after starting therapy, the present patient experienced polyuria and he was proven to have central DI. Therefore, if we had initially treated with maintenance dose of GC, the onset of polyuria might have occurred earlier and ODS might not have been prevented.

In general, the replacement of $\mathrm{GC}$ is done with maintenance doses $(4,5)$. As far as we know, there have been no reports stating that replacement of GC should be done initially with a low dose and gradually increased to maintenance doses. We cannot state categorically that our approach is best. However, considering that ODS is an often irreversible disorder, clinicians should carefully design GC treatment regimens.

In summary, we reported a patient with hyponatremia due to GC deficiency who also had masked DI. Using carefully designed GC replacement, serum sodium levels did not increase more than $10 \mathrm{mEq} / \mathrm{L} / \mathrm{day}$ and ODS did not occur. Gradual increment of GC dose may reduce the risk of ODS for patients with hyponatremia due to central adrenal insufficiency, especially when complicated by central DI.
The authors state that they have no Conflict of Interest (COI).

\section{References}

1. Sterns RH, Riggs JE, Schochet SS Jr. Osmotic demyelination syndrome following correction of hyponatremia. N Engl J Med 314: 1535-1542, 1986.

2. Brown WD. Osmotic demyelination disorders: central pontine and extrapontine myelinolysis. Curr Opin Neurol 13: 691-697, 2000.

3. Lasheen I, Doi SA, Al-Shoumer KA. Glucocorticoid replacement in panhypopituitarism complicated by myelinolysis. Med Princ Pract 14: 115-117, 2005.

4. Diederich S, Franzen NF, Bahr V, Oelkers W. Severe hyponatremia due to hypopituitarism with adrenal insufficiency: report on 28 cases. Eur J Endocrinol 148: 609-617, 2003.

5. Oelkers W. Hyponatremia and inappropriate secretion of vasopressin (antidiuretic hormone) in patients with hypopituitarism. N Engl J Med 321: 492-496, 1989.

6. Raff H. Glucocorticoid inhibition of neurohypophysial vasopressin secretion. Am J Physiol 252: R635-R644, 1987.

7. Yoshioka K, Tanaka N, Yamagami K, Inoue T, Hosoi M. Arginine vasopressin-independent mechanism of impaired water excretion in a patient with sarcoidosis complicated by central diabetes insipidus and glucocorticoid deficiency. Case Report Med 2011: 145856, 2011.

8. Okada K, Nomura M, Furusyo N, et al. Amelioration of extrapontine myelinolysis and reversible parkinsonism in a patient with asymptomatic hypopituitarism. Intern Med 44: 739-742, 2005.

9. Sugimura Y, Murase T, Takefuji S, et al. Protective effect of dexamethasone on osmotic-induced demyelination in rats. Exp Neurol 192: 178-183, 2005.

10. Pham PC, Pham PA, Pham PT. Sodium and water disturbances in patients with Sheehan's syndrome. Am J Kidney Dis 38: E14, 2001.

11. Lee WC, Cheng YF, Chen JB. Treating hyponatremia in an empty sella syndrome patient complicated with possible myelinolysis. Chang Gung Med J 25: 838-843, 2002.

12. Shoji M, Kimura T, Ota $K$, et al. Cortical laminar necrosis and central pontine myelinolysis in a patient with Sheehan syndrome and severe hyponatremia. Intern Med 35: 427-431, 1996.

13. Eguchi K, Uozumi T, Arita $\mathrm{K}$, et al. Pituitary function in patients with Rathke's cleft cyst: significance of surgical management. Endocr J 41: 535-540, 1994.

(C) 2012 The Japanese Society of Internal Medicine http://www.naika.or.jp/imindex.html 